Winter 2007

\title{
Lawyers as Sanctifiers: The Role of Elite Law Firms in International Business Transactions
}

John Flood

University of Westminster

Follow this and additional works at: https://www.repository.law.indiana.edu/ijgls

Part of the International Law Commons, and the Legal Profession Commons

\section{Recommended Citation}

Flood, John (2007) "Lawyers as Sanctifiers: The Role of Elite Law Firms in International Business Transactions," Indiana Journal of Global Legal Studies: Vol. 14 : Iss. 1 , Article 4.

Available at: https://www.repository.law.indiana.edu/ijgls/vol14/iss1/4

This Symposium is brought to you for free and open access by the Law School Journals at Digital Repository @ Maurer Law. It has been accepted for inclusion in Indiana Journal of Global Legal Studies by an authorized editor of Digital Repository @ Maurer Law. For more information, please contact rvaughan@indiana.edu.

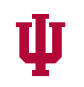

JEROME HALL LAW LIBRARY INDIANA UNIVERSITY Maurer School of Law
Bloomineton 


\title{
Lawyers as Sanctifiers: The Role of Elite Law Firms in International Business Transactions
}

\author{
JoHN FLOOD*
}

\section{Abstract}

Globalization has fundamentally accelerated and altered business transactions. The search for low labor costs and cheap raw materials has led to a proliferation of international transactions, and large, international law firms are called on to participate in complex transactions helping business tap into sources of finance around the world for investment. This article first examines the theoretical underpinnings of international legal practice, taking into account the historiography of U.S. and U.K. law firms. Part II describes the economic and political factors behind law firms' rise. Part III analyzes the success of the common law, as expressed through contract, at the expense of civilian codes. Part IV examines how international law firms have capitalized on their growth and success. Part V draws upon Luhmann's sociology of law to begin to explain how law firms achieve their aims by creating supporting and enabling structures for business. Part VI highlights a case study of the creation of a legal investment device, the U.K. Pfandbriefe. The conclusion suggests some ways of bringing these diverse strands together that explain law firms' roles in international business transactions through the management of uncertainty and stabilization of expectations.

*Professor of Law and Sociology, School of Law, University of Westminster, U.K. LL.B., London School of Economics and Political Science; LL.M., University of Warwick; LL.M., Yale Law School; Ph.D., Northwestern University; john.flood@care4free.net. The paper is part of a larger project, "New Forms of Legal Certainty in Globalized Exchange Processes" being conducted at the Collaborative Research Center 597, University of Bremen, which also provided funding and a home for the research. I am indebted to Volkmar Gessner for both his invitation to participate in the project and for his support. Pablo Sosa, a researcher within the project, has been a steadfast colleague. I owe thanks to a number of people for their critical evaluations: Pablo Sosa, Volkmar Gessner, Eleni Skordaki, Avis Whyte, Reza Banakar and Andy Boon. Earlier versions of this paper were presented at Self-Governance and the Law in Multinational Corporations and Transnational Business Networks Workshop, International Institute for the Sociology of Law, Oñati, June 2005 and Globalization of the Legal Profession Symposium at Indiana University School of Law, April 6, 2006.

Indiana Journal of Global Legal Studies Vol. 14 \#I (Spring 2007)

OIndiana University School of Law 


\section{Introduction: The Context and Legal Certainty}

Globalization has fundamentally accelerated and altered business transactions. The search for low labor costs and cheap raw materials has led to a proliferation of international transactions.' While the economics of these transactions have adapted to the demands of globalization with, for example, the use of complex derivatives' structures to hedge against various contingencies, the legal aspects remain deeply embedded within domestic laws rather than international law. Gessner, Appelbaum, and Felstiner have articulated four discourses "about the way businesses are supported and structured in the global environment." These form a continuum from universalistic to particularistic solutions:

$[O]$ ne emphasises the importance of formal legal rules, a second emphasises autonomous rules in the form of business self-regulation (lex mercatoria), a third focuses on the decisive role of the legal profession itself in structuring business relationships and in bridging the gap between legal cultures, and a fourth emphasising the importance of tightly-knit, informal business networks, as exemplified in the guanxi relationships of Chinese business culture. ${ }^{2}$

The purpose of this article is based on the third discourse, the role of the legal profession in business transactions. In particular, the focus is on the role of the large, international law firms. ${ }^{3}$ This broadly means attention here is fixed on the law firms of London and New York. The kinds of transactions that international law firms are called on to participate in are large, diverse, complex, and usually done under punitive time constraints. A key area of work for international law firms, for example, is capital markets, that is helping business tap into sources of finance around the world for investment. The two main sources are the London and New York markets and there is intense competition between them. An illustration of the kind

1. See generally The World Bank Group, Assessing Globalization: What is Globalization?, (April 2000), http://wwwl.worldbank.org/economicpolicy/globalization/ag01.html (discussing the rising amount of economic activity taking place between entities in different countries).

2. Volkmar Gessner, Richard P. Appelbaum \& William L.F. Felstiner, Introduction to Rules and Networks: The Legal Culture of Global Business Transactions 1, 8 (Richard P. Appelbaum, William L.F. Felstiner \& Volkmar Gessner eds., 2001) [hereinafter Rules and NetWORKs].

3. See also John Flood, Megalawyering in the Global Order: The Cultural, Social and Economic Transformation of Global Legal Practice, 3 Int'L J. Legal Prof. (Special Issue) 169, 170-71 (1996). 
of work undertaken will demonstrate the complexity and range of tasks. The island of Sakhalin on the eastern coast of Russia has extensive oil and gas reserves. It constitutes Russia's first offshore oil and gas project with an estimated cost of at least $\$ 9$ billion. ${ }^{4}$ Because of the environmental impact of the project, the Russian Production Sharing Agreement Law ${ }^{5}$ required certain local laws to be in place during the project. As only 70 percent of the necessary legislation was in place, ${ }^{6}$ the work of drafting the legislation was outsourced to one of the large law firms that provided the final draft of the legislation. The project involved expertise in environmental regulation, tax law, banking and financing, and regulatory issues-an extensive remit.

The massive scale of these projects creates massive scope for uncertainty. Through the creation of "typified solutions," that is, elaborate documentation, lawyers can bring a kind of legal certainty to the transaction. But it is a contingent certainty, one that is capable of being overturned for a number of reasons: "Social exchanges across borders are based on lower, more specific expectation structures like social roles ... or simply on personal relationships." Despite its contingent nature, there are benefits to this kind of certainty because it is formed in the embedded networks that come into play as the transaction progresses. ${ }^{8}$ As there is a relatively small number of players in the field, business flows to them with minimal or no costs of advertising. ${ }^{9}$ Reputation is easily ascertained and maintained providing stable market shares for the participants. Leifer reinforces this view when he says: "A

4. See Sakhalin-1 Project, http://www.sakhalinl.com/index.asp (last visited Nov. 13, 2006); Sakhalin Energy: The New Energy Source for the Asia-Pacific, Sakhalin-2 Project, Meeting the Energy Challenge, http://www.sakhalinenergy.com/en/ataglance.asp?p=aag_main\&s $=1$ (last visited Nov. 13, 2006). According to Shell, which at one time owned 55\% of Sakhalin-2, the project is costing " $\$ 100$ a second and occupying $60 \mathrm{~m}$ person-hours a year." Thomas Catan, Remote Resource: Shell's Sakhalin Task Shows an Industry Its Daunting Future, Fin. Times (London), Jan. 9, 2006, at 15, available at http://www.ft.com/cms/s/574fa34a-80b4-1lda-8f9d-0000779e2340.html.

5. Law of the Russian Federation on Production Sharing Agreements, Art. 7(2), Sobr. Zakonod. RF, 1995, No. 225-FZ, available at LEXIS, Rflaw File, GARANT 10005771.

6. John Flood, Capital Markets: Those Who Can and Cannot Do the Purest Global Law Markets, in Rules And Networks, supra note 2, at 249, 257.

7. Gessner, Appelbaum \& Felstiner, supra note 2, at 10.

8. See generally Mark Granovetter, Economic Action and Social Structure: The Problem of Embeddedness, 91 Ам. J. Soc. 481 (1985) (discussing the extent to which, in modern industrial society, economic action is embedded in structures of social relations); Brian Uzzi, The Sources and Consequences of Embeddedness for the Economic Performance of Organizations: The Network Effect, 61 AM. Soc. Rev. 674 (1996) (explaining how embeddedness offers unique opportunities and that firms organized in networks have a better chance of surviving than those firms that maintain arm's length market relationships).

9. Joel M. Podolny, A Status-Based Model of Market Competition, 98 Aм. J. Soc. 829, 838 (1993). 
small and identifiable group of producers, attached to brands, ... hold onto stable market (volume) shares. The reputations are not arbitrarily distributed across producers, but are often tied to market share."10 This is the case with large law firms.

This article first examines the theoretical underpinnings of international legal practice, taking into account the historiography of U.S. and U.K. law firms. Part II describes the economic and political factors behind law firms' rise. Part III analyzes the success of the common law, as expressed through contract, at the expense of civilian codes. Part IV examines how international law firms have capitalized on their growth and success. Part V draws upon Luhmann's sociology of law to begin to explain how law firms achieve their aims by creating supporting and enabling structures for business. Part VI highlights a case study of the creation of a legal investment device, the U.K. Pfandbriefe. Finally, in the Conclusions I suggest some ways of bringing these diverse strands together that explain law firms' roles in international business transactions through the management of uncertainty and stabilization of expectations.

\section{The Theory and History of International Legal Practice}

The rise of the international law firm seems unconquerable. One reason is that state and supranational lawmaking have not been able to stay abreast with the rapid developments in the globalization of law. The only institution that has marched in step has been the large international law firm. No global transaction-contract, distribution agreement, securitization, franchise-can be engineered without them. They have colonized the world of global law.

While the large law firm is a secular institution and globalization follows non-theocratic routes, large law firms nevertheless possess a sacred role. It is they who sanctify the relationships that global actors form when they engage in business. Without the imprimatur granted in the documentation of the large law firm, business dealings will always appear somewhat profane and suspect. Sacred institutions are generally formed with traditional authority and power vested at the top among a small number of individuals. The world of global business and law is none too different. Although law is depicted as a rational enterprise based on impersonal characteristics, the role of the international large law firm in this sphere is enshrined as a Weberian form of traditional authority. ${ }^{11}$ Authority, in

10. Eric M. Leifer, Markets as Mechanisms: Using a Role Structure, 64 Soc. Forces 442, 442-43 (1985).

11. See Max Weber, Economy and Society: An Outline of an Interpretive Sociolocy 21516 (Guenther Roth \& Claus Wittich eds., Bedminster Press 1968) (1956). 
this form, calls for legitimation that arises from the institutional legacy of habitualization and typification, which locates the institution of the large law firm in the sub-universe of law. Berger and Luckmann portray legitimation thus:

Legitimation "explains" the institutional order by ascribing cognitive validity to its objectivated meanings. Legitimation justifies the institutional order by giving a normative dignity to its practical imperatives. It is important to understand that legitimation has a cognitive as well as a normative element. In other words, legitimation is not just a matter of "values." It always implies "knowledge" as well.12

Legitimation may be distinguished at various levels, of which the highest are the symbolic universes, which "are bodies of theoretical tradition that integrate different provinces of meaning and encompass the institutional order in a symbolic totality...."13 Since the symbolic universe is the "matrix of all socially objectivated and subjectively real meanings,"14 the role of the large law firm is engaged as part of the normality of the symbolic universe. Although within the totality of meanings the large law firm is marginal-there are relatively few firms and the character of work is esoteric - "the symbolic universe provides the ultimate legitimation of the institutional order by bestowing upon it the primacy in the hierarchy of human experience."15 There is in place a double legitimation: the first refers to the legitimation process carried out by large law firms themselves within the context of international business transactions, and the second is the legitimation conferred upon the large law firm itself within the symbolic universe. Through the division of labor, large law firms have come to embody the traditional authority of the expert, an authority that is superior to most practitioners in the field.

In many ways international law firms resemble the Society of Jesus, the Jesuits. The formation of the Jesuits by Ignatius Loyola was constructed by careful testing of rules and customs, refusing to codify them until they had proven their worth over time and in different circumstances. ${ }^{16}$ One of their key aims was to proselytize overseas, which they did by establishing missions in the Americas and

12. Peter L. Berger \& Thomas Luckmann, The Social Construction of Reality: A TreaTISE IN THE SOCIOLOGY OF KNOWLEDGE 86 (1966).

13. Id. at 88 .

14. Id. at 89 .

15. Id. at 91 .

16. J. H. Pollen, The Society of Jesus, in New Advent Catholic Encyclopedia (2006), http://www.newadvent.org/cathen/1408la.htm. 
the Far East. They were convinced of the need to apply technical expertise on the church's behalf and thus set up many colleges and universities to train young men. Moreover, the order initiated its members as novitiates who spent many years studying before being selected as members of the "professed," the most senior order. Even the quotation attributed to St. Francis Xavier, co-founder of the Jesuits (1506-1532), "Give me the children until they are seven and anyone may have them afterwards," man," 18 is redolent of Cravath's training method for associates. ${ }^{19}$ The Jesuits also adhered to ritual based on Ignatian spirituality requiring devotion, meditation, and a zeal for saving the souls of others. ${ }^{20}$ Yet all this was to be done with a sense of detachment from immediate desires and interests.

The following example illustrates the role of law firms as a Jesuitical sanctifier, one that seeks the "salvation" of the participants' "souls." A $\$ 2$ billion 50/50 joint venture between Nissan, of Japan, and Dongfeng Motor, of the People’s Republic of China (PRC), was proposed. ${ }^{21}$ The key to the joint venture was the complete restructuring of the entire Chinese state-owned enterprise, not merely its subsidiaries. ${ }^{22}$ Crucial to the joint venture was a $\$ 1$ billion investment by Nissan into the new company, the largest foreign investment into the Chinese motor industry. ${ }^{23}$ Dongfeng's counsel on both the restructuring and the joint venture was Jones Day Reavis \& Pogue, a large U.S. law firm headquartered in Cleveland, Ohio, which used lawyers for this transaction from its Shanghai, Taipei, Tokyo, Los Angeles, and Cleveland offices. ${ }^{24}$ Even though PRC and Japanese law firms participated in the deal, only a law firm with the kudos and international stature of Jones Day could prove to the international financial community that such an arrangement was worthwhile, above board, and, more importantly, worth repeating. Jones Day, by virtue of its participation, was able to verify the bona fides of the transaction. Even if the transaction had been conducted fairly and competently by local, mainland PRC law firms, the level of belief would have been unacceptably low or nonexistent.

17. Seven UP (Granada Television 1964).

18. Wikipedia.org, http://en.wikipedia.org/wiki/Seven_Up! (last visited Jan. 11, 2007).

19. See 2 Robert T. Swaine, The Cravath Firm and Its Predecessors 1819-1849: The Cravath Firm Since 1906, at 4-5 (1948).

20. Pollen, supra note 16.

21. Press Release, Jones Day, Jones Day Counsels on Landmark Automobile Joint Venture in China (June 11, 2003), available at http://www.jonesday.com/news/news_detail.aspx? newsid $=229003$.

22. Id.

23. Id.

24. Id. 
To summarize, the large international law firm is a pillar of globalizationglobalization cannot succeed without the large law firm. How then did the large law firm come to occupy such a position? From whence did it come? My focus will primarily be on the law firms of the United States and the United Kingdom. That is not to say there are no large law firms elsewhere in the world, but rather that the Anglo-American law firm axis is the biggest and most important, and it possesses the most used body of law in international transactions.

\section{A. Law Firms in the United States}

According to de Tocqueville, lawyers have always enjoyed a relatively elevated status in the United States compared to France or the United Kingdom. ${ }^{25}$ For the United States, it was the industrial revolution and the spread of the railroads that spurred the growth in numbers of law firms and their sizes. ${ }^{26}$ Despite the United States developing later than the United Kingdom, the large law firm emerged first in the United States rather than the United Kingdom. The year 1870 not only marked a surge in commerce and business in the United States but also the rise of the new American law school when Christopher Columbus Langdell became dean of Harvard Law School. Langdell borrowed the pedagogical techniques of the chemistry laboratory to create the case method of teaching law, ${ }^{27}$ which enabled law students to be finely graded and, with the best students becoming the editors of the law review, law firms were able to select the most qualified graduating students as their new associates. Law firm recruitment could move away from socially-based ascription toward merit-based selection. While Langdell provided the model for the new law school, Cravath, a New York attorney, was devising improvements to, and creating the organization of, the new corporate law firm. ${ }^{28}$ He became the Ignatius Loyola of legal practice. All of these moves were part of the idea that law was a science. ${ }^{29}$

25. See 1 Alexis De Tocqueville, Democracy in America 326-28 (Henry Reeve trans., Schocken Books 1961) (1835).

26. Robert W. Gordon, The American Legal Profession, 1870-2000, in Cambridge History of Law in A MERICA (Christopher Tomlins \& Michael Grossberg eds., forthcoming 2007) (manuscript at 20-21, on file with author).

27. See Robert Stevens, Law School: Legal Education in America from the 1850s to the 1980s 52-53 (1987).

28. See generally Swaine, supra note 19, at 1-12 (explaining the key features of the "Cravath Firm" and the "Cravath System").

29. Gordon, supra note 26 , at 15. 
Typically, new lawyers worked as associates for their employers' clients as well as for their own. This division of labor created a concomitant division of loyalties between firm and client. Moreover, there was no guarantee that an associate would be made a partner within the firm. Cravath altered that unsatisfactory state of affairs by refining the "up or out" method of law firm management. An associate would be hired on probation for several years and would work only on matters for the firm's clients. At the end of a successful probation, the associate could expect to become a partner. If he did not make partner, the firm would attempt to place him in the office of one of its clients. ${ }^{30}$ The system maintained associates' motivation and loyalty to the firm and simultaneously removed disaffected associates and cemented good and enduring relations with the firms' clients. According to Galanter and Palay, this mode of law firm organization set law firms on a steady course of exponential growth. ${ }^{31}$ Law firm histories show New York law firms growing rapidly. ${ }^{32}$ Sullivan \& Cromwell, for example, had over 200 lawyers by the 1930s, causing Karl Llewellyn to caution about law factories mopping up all the best lawyers, leaving too few to do the remaining "law jobs" in society. ${ }^{33}$

During this period large law firms ceased to be shifting constellations of individuals - although individuals could exert enormous influence, as, for example, John Foster Dulles in Sullivan \& Cromwell and, later, at the State Department ${ }^{34}$ and became recognizable institutions with clear brand names. The firm itself became the crucial and also publicly visible entity.

\section{B. Law Firms in the United Kingdom}

Despite entering the Industrial Revolution earlier than the United States, and even enjoying global aspirations through the British Empire, the practice of law in the United Kingdom remained a cottage industry. The term "law factory" did not gather salience until the post-World War II period. Nevertheless, corporate

30. See id. at 42.

31. Marc Galanter \& Thomas Palay, Tournament of Lawyers: The Transformation of THE Big LaW Firm 99-108 (1991).

32. See generally John Flood, Resurgent Professionalism? Partnership and Professionalism in Global Law Firms, in Redirections in the Study of Expert Labour (S. Ackroyd, G.D. Muzio \& J.F. Chanlet eds., forthcoming 2007) (discussing the development of specific New York firms).

33. K. N. Llewellyn, The Bar Specializes-With What Results?, 167 Annals Am. Acad. Pol. \& Soc. Scı. 177, 177-79 (1933).

34. See generally Nancy Lisagor \& Frank Lipsius, A Law Unto Itself: The Untold Story of the Law Firm Sullivan \& Cromwell 99-118 (1988) (discussing the rise and fall of John Foster Dulles in his career at the law firm of Sullivan \& Cromwell). 
law firms developed, some with grand and important lineages and connections such as Freshfields, lawyers to the Bank of England. ${ }^{35}$

The United Kingdom also came late to modern legal education but it never developed along U.S. lines of the Socratic dialogue, preferring the traditional unidirectional lecture model. ${ }^{36}$ English law did not have the "scientific" pretensions of U.S. law. Recruitment, as befitted the English class system, followed ascriptive selection based on family linkages. ${ }^{37}$ Unlike U.S. law firms, English solicitors and barristers did not pay salaries to their young lawyers; conversely, they required premiums from them for the privilege of working in the practice. The expansion of English law firms was capped by various companies' acts limiting partnership numbers to no more than twenty partners until 1969. Even though English firms had flat profiles like their U.S. cousins, the Cravath-type process never occurred because of the arbitrary limits and lack of merit-based selection. English law firms therefore remained small in comparison to the U.S. firms until the lifting of the partnership cap and the growth in legal and commercial work in the 1970 s. $^{38}$

\section{The Move Toward Flexible Partnership}

Partnership was traditionally considered a marriage for life with little thought of divorce. This typification is exemplified in Emmanuel Lazega's study of a New England corporate law firm, which followed the classic partnership model..$^{39}$ Partners were remunerated by lockstep and the possibility of defections was managed by the judicious allocation of resources, mostly associates, to partners. Partners embraced feelings of autonomy and yet participated in the collective by virtue of a set of interdependent resource networks, which meant they had to collaborate in order to do their work. In the last twenty years of the 20th century, law firms have rethought their organizational forms. Size has brought management and bureaucracy, both usually anathema to lawyers, and undermined the traditional profes-

35. Judy Slinn, A History of Freshfieldo 159 (1984).

36. William Twining, Blackstone's Tower: The English Law School 79 (1994).

37. See, e.g., SLIN N, supra note 35, at 53-70 (discussing how eight members of the Freshfield family, spanning four generations, became partners in the firm).

38. Flood, supra note 3, at 178-79.

39. See generally Emmanuel Lazega, The Collegial Phenomenon: The Social Mechanisms of Cooperation Among Peers in a Corporate Law Partnership (2001) (using a corporate law partnership as an example of a specific collegial organization in which partners lock themselves into a long-term situation). 
sional partnership but not completely negated it. In its place a new organizational archetype emerged, namely, the managed professional business (MPB). ${ }^{40}$ Management has also brought in its train measurement, scaling, ranking, and targets. MPBs celebrate this through the use of "eat what you kill" types of remuneration. ${ }^{41} \mathrm{MPB}$ also engage in rational strategic market behaviors with high levels of intra-firm specialization. Partners are required to fulfill goals along with their associates. Goal-setting for partners has been further emphasized by the increase in the rate of introduction of two-tier and multi-tier partnerships, thereby extending probation periods. ${ }^{42}$ Failure to achieve specified targets has meant the easing out, or de-equitization, of partners. ${ }^{43}$ Of course, if partners can be eased out, then they can also leave. Individual lawyers and even teams of lawyers began to move from firm to firm, taking their clients with them, sometimes following the lure of more money, other times in search of new markets and greater autonomy. Partnerships have become shifting constellations of lawyers with a diminishing sense of loyalty to the firm. ${ }^{44}$ To compound the centrifugal force, law firm mergers with their inevitable disjunctions of cultures have become de rigueur. The modern large law firm has thus truly become a business, a law factory, in a highly competitive market.

\section{From Strong to Weak Ties}

The move toward MPBs has been accompanied by a fundamental shift in the structure of lawyer-client relationships. The core of large law firm practice was a stable of repeat, durable clients who fed their entire range of legal work to their firm. Milbank Tweed Hadley \& McCloy is a classic case in point: the firm

40. C. R. Hinings, Royston Greenwood \& David Cooper, The Dynamics of Change in Large Accounting Firms, in Restructuring the Professional Organization: Accounting, Health Care And Law 131, 152 (David M. Brock, Michael J. Powell \& C.R. Hinings eds., 1999).

41. See generally Milton C. Regan, Jr., Eat What You Kill: The Fall of a Wall Street LaWyer 15-49 (2006) (discussing the transition from the "nobody starves" mentality to "eat what you kill").

42. See generally William D. Henderson, An Empirical Study of Single-Tier Versus Two-Tier Partnerships in the Am Law 200, 84 N.C. L. Rev. 1691 (2006) (discussing the advantages and disadvantages of single-tier versus two-tier partnerships).

43. See Leonard Bierman \& Rafael Gely, So, You Want To Be a Partner at Sidley \& Austin?, 40 Hous. L. Rev. 969, 989 (2003).

44. See, e.g., Lincoln Caplan, Skadden: Power, Money, and the Rise of a Legal Empire 6371 (1993); Kim Isaac Eisler, Shark Tank: Greed, Politics and the Collapse of Finley Kumble, One of A merica's Largest Law Firms 209 (1990). 
handled all the Rockefeller family's business as well as the banking work of their bank, Chase National. ${ }^{45}$ During the 1970 s the ties began to weaken between law firms and their clients. ${ }^{46}$ Two reasons suffice here: the first is that law firms themselves were weaker organizations with far more lawyer movement and lateral hiring, reducing firm loyalties; the second is that corporations took more of their legal work in-house and expanded their legal departments. Law firms were hired not so much for their history with their clients but rather their competence in particular transactions. The rise of Skadden and Wachtell Lipton are examples of law firms that targeted specific kinds of work, e.g., hostile takeovers, and concentrated on transactions at the expense of forming long-term client relationships. ${ }^{47}$ These shifts to transactional work have had repercussions throughout the legal profession and legal work: beauty parades have become part of the normal currency of obtaining work, law firms have to take account of diversity, ${ }^{48}$ and have to consider the role of corporate social responsibility in their legal advice. ${ }^{49}$

\section{Engines of Global Legal Growth}

In many respects the Cold War was a golden era for international law firms. The West was out to ensure the world adhered to ideas of liberal democracy and free market economics - the Washington consensus - and not be seduced by irrational notions of socialist state-centered economic planning. ${ }^{50}$ States assisted business in promoting its interests overseas and lawyers drafted the documenta-

45. Kai Bird, The Chairman: John J. McCloy, the Making of the American EstablishMENT 273-74 (1992).

46. John P. Heinz, Robert L. Nelson \& Edward O. Laumann, The Scale of Justice: Observations on the Transformation of Urban Law Practice, 27 Ann. Rev. Soc. 337, 346-49 (2001).

47. See Caplan, supra note 44, at 202-27; William H. Starbuck, Keeping a Butterfly and an Elephant in a House of Cards: The Elements of Exceptional Success, 30 J. Mgmr. Stud. (Special Issue) 885,885 (1993).

48. David B. Wilkins, Why Global Law Firms Should Care about Diversity: Five Lessons From the American Experience, 2 Eur. J.L. Reform 415, 417-19 (2000).

49. See generally Halina Ward, Int'l Inst. for Environment and Development, Corporate ResponsibiLity and THE Business of LAw (2005), available at http://www.iied.org/SM/CR/documents/Corporateresponsibilityandthebusinessollaw.pdf (reporting on the implications of the corporate responsibility agenda for the practice of business law); Halina Ward, The Interface Between Globalisation, Corporate Responsibility, and the Legal Profession, 1 U. Sт. Tномаs L.J. 813 (2004) (discussing the importance of integrating legal ethics and corporate social responsibility).

50. See generally Martin Wolf, Why Globalization Works 36-39 (2004) (discussing how the acceptance of liberal democracy has been common to all advanced market economies). 
tion that guaranteed its success. Moreover, lawyers were implicated in the process all the way through. John Foster Dulles of Sullivan \& Cromwell was U.S. Secretary of State; ${ }^{51}$ his brother, Allan, was director of the Central Intelligence Agency; ${ }^{52}$ John J. McCloy of Milbank Tweed was Allied High Commissioner for Germany and lead the German Marshall Plan; ${ }^{53}$ and George Ball of Cleary Gottlieb was conferring with Jean Monnet on the European Economic Community ${ }^{54}$ and helping establish Cleary offices in Paris in $1949^{55}$ and in Brussels in $1960 .{ }^{56}$ More were in the wings.

The main impetus for growth in global legal work came from the rapid development of financial and capital markets. ${ }^{57}$ Through the 1960 s the Eurodollar and Eurobond markets were establishing themselves and requiring massive amounts of legal documentation. By the 1970s, with the extreme rent-seeking behavior of the Organization of Petroleum Exporting Countries (OPEC), the world's banking system became shaky and bankruptcy and restructuring work became more prevalent in the United States and United Kingdom. It was, however, the opening up of the capital markets especially in the global cities of New York, London, and Tokyo, ${ }^{58}$ that helped the "Big Bang" deregulation of London's financial markets. Banks moved from lending directly and adopted the role of broker and adviser, i.c., disintermediation, assisting business in taking many of its liabilities off the balance sheet through techniques like securitization. ${ }^{59}$ U.S. banks found that by opening offices in London they could avoid the strictures of the Glass-Steagall Act of 1933 that restricted their domestic activities. The 1980 s were

51. Lisagor \& Lipsius, supra note 34 , at 165.

52. Id. at 203.

53. Thomas Alan Schwartz, America's Germany: John J. McCloy and the Federal RepubLic of Germany 40-42 (1991).

54. James A. Bill, George Ball: Behind the Scenes in U.S. Foreign Policy 109 (1997).

55. Id. at 102 .

56. Cleary Gottleib, About the Firm, Firm History, http://www.cgsh.com/english/about/about. aspx? id =000320919205 (last visited Nov. 13, 2006).

57. See generally David Held, Anthony McGrew, David Goldblatt \& Jonathon Perraton, Global Transformations: Politics, Economics and Culture 218, 234-35 (1999) (discussing the exponential growth in global finance).

58. Saskia Sassen, The Global City: New York, London, Tokyo 171-72 (2d ed. 2001); see also Posting of Bill Henderson, Global Cities and Law Firms, to Empirical Legal Studies, http://www. elsblog.org/the_empirical_legal_studi/2006/07/global_cities_a.html (July 13, 2006, 06:47 EST) (naming New York the top U.S. "global city" as a hub for international commerce).

59. See John Flood, Capital Markets, Globalisation and Global Elites, in Transnational Legal Processes: Globalisation and Power Disparities 114, 117 (Michael Likosky ed., 2002) [hereinafter Transnational Legal Processes]. 
a ferment of financial activity as derivatives markets multiplied their products and employed the power of leverage. ${ }^{60}$ This growth has continued to the present day.

\section{Explaining the Success of Common Law}

All these activities needed creative lawyering to facilitate their progress and deal with the regulatory obstacles that were put in their way. The type of law practice that could facilitate business had to be expert, well-connected with the regulatory authorities, and know how to invoke disputing practices as well as negotiating skills. ${ }^{61}$

The sociologist Max Weber argued that the best form of lawmaking for modern capitalism would be formally rational, that is, internally coherent without having to appeal to any phenomena or noumena external to the system. ${ }^{62}$ Formal rationality was, for Weber, idealized within the civilian system of lawmaking, but the advance of capitalism was not located within the countries that subscribed to civil codes. ${ }^{63}$ Instead, real progress was found within systems of substantive rationality, which, although coherent, would invoke appeals to external forces such as policy or custom. The result of the openness of the substantively rational systems was that they possessed a malleability unfound in the civilian systems. Given the speed at which financial markets were pushing, lawmaking had to respond with similar alacrity.

Embodied within this concept of lawmaking was a particular style of lawyering and reproduction of lawyers. The civilian codes were bound up with niceties and distinctions of the academic lawyers constantly seeking to polish and refine their internally coherent systems. This push toward consistency was made at the expense of rapid response to situations as they occurred in real time. It is not surprising therefore that the academies took the prime role in producing the future generations of lawyers, imbuing them with a reverence for the sanctity of the code above all else.

60. See Flood, supra note 3, at 186; Flood, supra note 6, at 253-58.

61. According to Marc Galanter and Joel Rogers, from the University of Wisconsin Law School, business added the strategies of litigation and disputing to its armory without expecting their deployment to interfere with the course of normal business relations. Making love and war were no longer mutually exclusive. See generally Marc Galanter \& Joel Rogers, The Transformation of American Business Disputing? Some Preliminary Observations (Inst. for Legal Studies, Disputes Processing Research Program, Working Paper No. 10-3, 1991).

62. See WeBER, supra note 11, at 641-43.

63. See Anthony T. Kronman, Max Weber 118-46 (1983). 
Weber clearly observed the paramountcy of the English bar in responding to commercial exigencies. The common law system was piecemeal, ad hoc, with no desire to be polished to some pristine state. It was content to be rough, as were its practitioners, who although they did not entirely scorn the academy, frequently took degrees in subjects other than law. Their training in law came through apprenticeship, learning on the job. Law was a craft skill - a form of "cautelary jurisprudence" - not a theoretical pursuit for philosophers. As Weber put it:

Not only was systematic and comprehensive treatment of the whole body of the law prevented by the craftlike specialization of the lawyers, but legal practice did not aim at all at a rational system but rather at a practically useful scheme of contracts and actions, oriented towards the interests of clients in typically recurrent situations. ${ }^{64}$

Anglo-American jurisprudence was unfettered and not beholden to law as an idealistic form.

The advantage of common law was that freedom of contract meant freedom to construct contracts as freestanding documents not tied to the ambitions of a code prowling in the background. Typical continental contracts are only a few pages in length, whereas the usual English or American contract will run to hundreds or thousands of pages or more with schedules. Nothing is left to external confirmation: if it is not in the contract it does not exist. ${ }^{65}$ Contract creates a system of private ordering that invokes the state symbolically but obscures it in regard to actual conduct. ${ }^{66}$ Here, contract means the privatization of law. And here lies the advantage of the Anglo-American system and its practitioners and the reason they have been successful in the international arena.

Since contract allows for virtually any normative system to constitute its base, choice of law is made for instrumental purposes rather than concerns of jurisdictional fidelity. Furthermore, if financial services are one of the key engines of globalization, then the number of salient jurisdictions with appropriate rules and norms are relatively few. In fact, there are for all practical purposes only two: English law and New York state law. ${ }^{67}$ They are represented by the city principalities of

64. WEBER, supra note 11 , at 787.

65. I have observed an ancillary explanatory document attached to a large securitization that ran for 50 pages defining the terms of the contract. The first term was 'day,' which was defined as 24 hours. 66. See Mark C. Suchman, The Contract as Social Artifact, 37 Law \& Soc'y Rev. 91,91 (2003).

67. Flood, supra note 59 , at 115. 
London and New York. The cities are emblematic of their states' legal, financial, and cultural power and authority ${ }^{68}$ Most transnational agreements will at some stage be transcribed into one or both of these systems. Thus, New York and London law firms possess distinct advantages over firms from other jurisdictions. Moreover, these law firms will actively market their jurisdictions-it's what they know bestand they are keen to maintain their competitive advantage. For example, in its reply to the British government's 1989 Green Paper on the work and organization of the legal profession, the City of London Law Society wrote: "The advantages of English law as a 'product' enable solicitors to contribute to this country's balance of payments some $£ 25,000,000$ per annum in invisible exports and constitute an important part of the attraction of the City of London as a world financial centre."'ts

Despite the internal benefits and strengths of Anglo-American law to international transactions, there are other reasons for its dominance. One explanation can be found in the concept of path dependence. It creates particular disincentives to market entry for others because there are substantial transaction costs involved in the attempt. The examples of the QWERTY typewriter keyboard and VHS video tapes confirm how sets of early and continuing adopters can create historical lock-ins that are difficult to change, i.e., "increasing returns to adoption."

\section{The Rise of the International LaW Firm}

The first point to make is that there are relatively few of these large law firms within the general population of law firms. They are, however, big: the largest of them have over 3000 lawyers located in offices throughout the world. Nevertheless, they are small in comparison to the major accounting firms. For example, PricewaterhouseCoopers has "a combined headcount" of more than 140,000 professionals working in 771 offices in 149 countries. $^{71}$ In contrast, Clifford Chance has 3,200 lawyers ${ }^{72}$ in 29 offices in 20 countries, ${ }^{73}$ and Baker \& McKenzie has 3,400 attorneys in 70 offices in

68. See Sassen, supra note 58, at 4.

69. City of London Law Soc'y, The Work and Organization of the Legal Profession: A Response to the Government's Green Paper 5 (1989).

70. W. Brian Arthur, Competing Technologies, Increasing Returns, and Lock-In By Historical Events, 99 Econ. J. 116, 116 (1989).

71. PriceWaterhouseCoopers, 2006 Global Annual Review, http://www.pwc.com (follow "Our Global Annual Review" hyperlink; then follow "Facts and Figures" hyperlink; then follow "People" hyperlink) (last visited Nov. 15, 2006).

72. 2005 UK 100 Annual Report, Top 100 Profile, Clifford Chance, http://www.thelawyer.com/ uk 100/2005/law/1_cliffordchance.html (last visited Nov. 15, 2006).

73. Clifford Chance, About the Firm, http://www.cliffordchance.com/about_us/about_the_ firm (last visited Nov. 15, 2006). 
38 countries. ${ }^{74}$ One effect of the enormous growth in law firms has been the intensification of specialization within them and also between offices in the same firm. Each department or section inside a firm has become a firm within a firm, or rather the firm becomes a set of networks. ${ }^{75}$ Besides the competition between firms for clients and work, competition also exists within firms where departments are in constant battle with each other for resources and remuneration. This is exemplified by Lazega's analysis of the internal Montesquieu structures within firms that operate to prevent fission. ${ }^{76}$ The general move to "eat what you kill" remuneration, however, has militated against some of these preventative measures and served to intensify competition between lawyers, creating a far more fluid market for lawyers between firms. ${ }^{77}$

"The Global 100" law firm survey produced by The Lawyer and American Lawyer shows that only eight of the listed top fifty firms are based in the United Kingdom. The remainder are headquartered in the United States. ${ }^{78}$ Although the U.K. firms are in a minority, they have a strong presence as illustrated by their gross revenue figures. Of the top nine firms grossing over $\$ 1$ billion, four are London firms-Clifford Chance, Linklaters, Freshfields Bruckhaus Deringer, and Allen \& Overy. ${ }^{79}$ These billion dollar club law firms are evenly spread among New York, London, and Chicago. ${ }^{80}$

74. Baker \& McKenzie, Firm Profile, Key Facts \& Figures, http://www.bakernet.com/Baker$\mathrm{Net} /$ Firm +Profile/Key+Facts +Figures/default.htm (last visited Nov. 15, 2006).

75. Gerard Hanlon, Lawyers, the State and the Market: Professionalism Revisited 12930 (MacMillan Press LTD 1999).

76. See generally LAZEGA, supra note 39, at 182-200 (arguing that the Montesquieu structure keeps a balance of power between different niches in collegial organizations).

77. See Regan, supra note 41, at 34.

78. See 2005 UK 100 Annual Report, Global 100, Top 100: 1-25, http://www.thelawyer.com/ globall00/2006/tb_1-25.html (last visited Nov. 15, 2006) [hereinafter Global 100: 1-25]; 2005 UK 100 Annual Report, Global 100, Top 100:26-50, http://www.thelawyer.com/global100/2006/tb_ 26-50.html (last visited Nov. 15, 2006) [hereinafter Global 100:26-50].

79. See The Lawyer Global 100 2005, http://www.thelawyer.com/global100/2005 (follow "Top 100: 1-25" hyperlink and "Top 100: 26-50" hyperlink to view the top 50 firms) (last visited Sept. 24, 2006). However, it has been reported that Clifford Chance has become the first law firm to achieve a turnover of more than $\mathrm{fl}$ billion, mostly on the back of national and multinational mergers and acquisitions and business advising on 444 deals globally, valued at a total of $\$ 490$ billion ( $f 260$ billion). Robert Verkaik, City Law Firm Clifford Chance is World's First flbn Legal Business, THE INDEPENDENT (London), Aug. 25, 2006, at 18.

80. See Henderson, supra note 58 (discussing the expansion of law firms in the global cities). For a chart illustrating the connections between capital and law practice, showing in which cities the majority of Fortune Global 500 companies are headquartered, see Fortune Global 500 2006, Top Cities, (July 24, 2006), http://money.cnn.com/magazines/fortune/global500/2006/cities/. The key law firms in the major cities are known as the 'Charmed Circle' in New York, which includes 
The disparity in U.K. and U.S. law firms is further highlighted in the profits per partner figures. Nearly all eight law firms in "The Global 100" with profits per equity partner (PEP) of more than $£ 1$ million ( $\$ 1.9$ million) are based in the United States with an emphasis on New York. At the top is Wachtell Lipton with a PEP exceeding $£ 2$ million $(\$ 3,790,000)$. Only a single U.K. firm, Slaughter and May, breaks the $£ 1$ million PEP barrier at $£ 1.05$ million ( $\$ 1.9$ million). If the revenue per lawyer (RPL) statistics are examined, which, according to Bruce MacEwen, "[i]t's a lot harder to game total revenue and number of lawyers than it is to game profitability. This strikes me as a pretty hard number, all things considered, ${ }^{\text {'ri }}$ then the certainty that the U.S. law firms are making more money than U.K. firms is inescapable. Only two U.K. firms within the top fifty global law firms muster an RPL of $£ 400,000$ and above. ${ }^{82}$ Consider further two firms of comparable stature and size: Slaughter and May (London) with 575 lawyers and 121 partners; and Cravath Swaine \& Moore with 389 lawyers and 79 partners. ${ }^{83}$ Both firms have eschewed growth by spawning very few overseas offices, relying on loose affiliations with local firms elsewhere. Cravath generates PEP of $£ 1.2$ million compared to Slaughter's $£ 1.05$ million. ${ }^{84}$ The revenues per partner are $£ 3.14$ million for Cravath and $£ 2.2$ million for Slaughter and May. ${ }^{85}$ And, finally, the RPL for Cravath is $£ 638,000$ compared to $£ 504,000$ for Slaughter. ${ }^{86}$ On the surface the two firms do more or less the same types of work, employ similar types of lawyers, and have the same kinds of clients, but there is a significant difference between the two that explains to some extent why U.S. law firms may succeed in areas where U.K. firms do not.

Since the U.S. legal profession has no artificial divisions of labor like the British profession, U.S. lawyers are expected to offer a full-range service that inevitably includes litigation expertise. A firm like Cravath, for example, handles full-scale capital markets work in tandem with defending the New York Times in court in high-profile First Amendment cases. English law firms typically out-

seven firms, and the 'Magic Circle' in London with five firms. International Firms: Trying to Get the Right Balance, The Economist (London), Feb. 28, 2004, at 65 [hereinafter International Firms].

81. Adam Smith, Esq., The 2006 AmLaw 100: Ranked by Revenue Per Lawyer, http:/www. bmacewen.com/blog/archives/2006/04/the_2006_amlaw_100_ranked.html (Apr. 29, 2006, 10:27 EST).

82. See The Lawyer Global 100 2005, 1-25 Full Table, http://www.thelawyer.com/ global100/2005/top 1-25.pdf (last visited Jan. 11, 2007) [hereinafter 1-25 Full Table]; The Lawyer Global 100 2005, 26-50 Full Table, http://www.thelawyer.com/global100/2005/top26-50.pdf (last visited Jan. 11, 2007) [hereinafter 26-50 Full Table].

83. 26-50 Full Table, supra note 82.

84. Id.

85. Id.

86. Id. 
source the court/advocacy parts of their litigation work to the $\mathrm{Bar},{ }^{87}$ and are only beginning to acquire the capacity to take cases into court without using barristers, but that is still exceptional. ${ }^{83}$ Furthermore, when English law firms have set up in cities like New York, their inexperience in litigation and their difficulty in attracting good U.S. litigators have held them back.

The distinction between the two legal cultures is important because of my earlier reference to the way business is now conducting its relationships. Engaging in disputes no longer necessarily means either, in Macaulay's terms, ignoring the contract and thrashing it executive to executive without the intervention of lawyers, or going to court and breaking the business relationship. ${ }^{89}$ Business is more likely to adopt the full range of techniques, legal and extra-legal, including litigation, arbitration, alternative dispute resolution, and negotiation, without anyone sounding the death knell to the business relationship. The upshot is that clients expect their law firm to provide them with a full menu of legal services. U.S. law firms are structured to provide this range; U.K. firms are lacking key areas. While it may seem that litigation expertise is only of use within domestic jurisdictions and therefore of little value to the global lawyer, the converse is actually true. Litigation expertise is called for in arbitration as well as in other non-state forms of dispute settlement. Dezalay and Garth have indicated that U.S. law firms have succeeded in breaking the stranglehold of the old European notables in international arbitration by offering a formalized, U.S. style approach — technocratic as opposed to aristocratic-one that is less dependent on personality and culture and more on rules. ${ }^{90}$

U.S. law firms are, at bottom, supported by a large domestic law market. ${ }^{91}$ Going global for them is dependent on the sustained development of their origi-

87. John Flood, Barristers, in 1 Legal Systems of the World: A Political, Social, and Cultural EnCYCLOPEdia 130, 131 (Herbert M. Kritzer ed., 2002).

88. Andy Boon \& John Flood, Trials of Strength: The Reconfiguration of Litigation as a Contested Terrain, 33 Law \& Soc'y Rev. 595, 595-96 (1999).

89. See Stewart Macaulay, Non-Contractual Relations in Business: A Preliminary Study, 28 Aм. Soc. Rev. 55, 60-62 (1963).

90. See Yves Dezalay \& Bryant G. Garth, Dealing in Virtue: International Commercial Arbitration and the Construction of a Transnational Legal Order 302 (1996). But see Fabian Sosa, Different Strategies of Mega and Midsized Law Firms to International Lawyering: The Example of International Commercial Arbitration 11 (2006) (working paper, on file with U. of Bremen Collaborative Research Center 597) (critiquing the Dezalay and Garth study). For a short history on international courts of arbitration and a description of new challenges they face, see Robert Briner, Globalization and the Future of Courts of Arbitration, 2 EUR. J.L. ReForm 439 (2000).

91. See Carole Silver, Globalization and the U.S. Market in Legal Services-Shifting Identities, 31 Law \& Pol'y Int'l Bus. 1093, 1099-1100 (2000). 
nal markets. The success of firms like Cravath and Wachtell Lipton exemplifies the policy of primarily concentrating on their home markets and using networks of overseas law firms to build their international practices. ${ }^{22}$ U.K. firms have never really possessed the luxury of a big domestic market and therefore have always had to seek work outside the United Kingdom. ${ }^{93}$ The empire provided conduits into profitable regions such as the Middle East and Asia. The globe has reconfigured itself with major regions becoming established, such as the European Union, North American Free Trade Agreement, and possibly the Association of South Eastern Asian Nations. The big three regions represent the bulk of inward and outward foreign direct investment flows in the world. ${ }^{94}$ Moreover, they have established their own disputing regimes, with even organizations such as the World Trade Organization developing their own jurisprudence through dispute panels.

An advantage enjoyed by U.S. firms is their long ties with investment bank clients. ${ }^{95}$ The major investment banks that engage in the capital market deals are all from the United States, e.g., Goldman Sachs, Morgan Stanley, and Merrill Lynch. We know from law firm histories that these ties go back more than 100 years. And strangely, though the lawyer-client relationship has undergone something of a change in recent years, from one-stop shop to transactional relations, some of these particular ties have endured.

While some firms have been able to rely on such traditional ties, the changes in the business landscape brought about by mergers and acquisitions, restructurings, and so forth, have made lawyer-client relations more tentative. In house counsel are stricter in regard to legal budgets, often asking law firms to commit to beauty parades to obtain work. Law firms have to market themselves and enlist the aid of the state in opening legal markets for them. ${ }^{96}$

92. See International Firms, supra note 80, at 67.

93. John Morris, one of the founders of Ashursts, a City of London corporate law firm, was, in the late $19^{\text {th }}$ century, "'a director of 13 successful public enterprises' who had 'frequently been employed ... to start at a few hours' notice, on a voyage across the Atlantic to assist in unravelling some vast complication in the American railway system." Laurie Dennett, Slaughter and May: A Century in the City 23 (1989).

94. See Held, McGrew, Goldblatt \& Perraton, supra note 57, at 250-51.

95. See Flood, supra note 6, at 254-55.

96. For an example, see Lord Falconer of Thoroton, Constitutional Affairs Secretary and Lord Chancellor, Keynote Address at the KPMG Annual Law Lecture, London: International Opportunities (Jan. 26, 2006) (transcript available at http://www.dca.gov.uk/speeches/2006/sp060126.htm), wherein he states, "I want to talk this evening about how we retain our position at the leading edge of the international trade in legal services. How we encourage exports, by helping lawyers who wish to work in other countries; and promote imports by encouraging the use of this country as a place to settle disputes.... As I am sure you are aware, the U.K. Government, through the European Commission, takes part in the 
Acting globally while thinking locally is fine as long as a firm is not constrained by local mores. The crucial question is to what extent international law firms are merely exporting English or New York law as opposed to engaging in the practice of local law. The U.K. Lord Chancellor has said:

Our common law of contract is now a world-wide commodity. It has become so because it is a system that people like. In ever more complex, sophisticated and inter-related markets, English commercial law provides predictability of outcome, legal certainty and fairness. It is clear and is built upon well-founded principles, such as the ability to require exact performance and the absence of any general duty of good faith. ${ }^{97}$

The large law firm's main alliance is with the Anglo-American nexus, which is composed of, among other things, neo-liberal democracy and respect for property rights as exemplified in the Washington Consensus. It therefore has to create ways to tie in local norms to the overarching pattern devised in English and U.S. law. Finding ways of dovetailing sometimes incommensurable systems has led to the globalization of legal education and training. Young lawyers from jurisdictions outside the Anglo-American nexus now find it essential to obtain an LL.M. degree at a major U.S. or U.K. law school, otherwise they will not be conversant with global legal techniques. ${ }^{98}$ Some reinforcement for this view is found within intergovernmental organizations such as the World Bank, which usually insist on their lawyers possessing a master's degree. Yet, as one big law firm partner said, "It doesn't matter where you got your legal education as basically we do the same thing over and over. Once you've been trained in the firm you have your skills."

\section{Creating and Providing Support Structures}

Luhmann's development of law starts with a world characterized by complexity and contingency. "Complexity in practice means compulsion to select, contin-

General Agreement on Trade in Services-GATS—negotiations within the WTO. The U.K. objective in these negotiations is to persuade as many countries as possible to make liberalising commitments."

97. Id.

98. See Carole Silver, The Case of the Foreign Lawyer: Internationalizing the U.S. Legal Profession, 25 Fordham INT'L L.J. 1039, 1040 (2002). For a discussion on how law schools in the U.S. and U.K. are responding to the demand for global legal education, see John Flood, Legal Education, Globalization, and the New Imperialism, in THe LaW SchoOL-Global Issues, Local Questions 127, 140-44 (Fiona Cownie ed.,1999).

99. Interview with large law firm corporate lawyer, in London, Eng. (Apr. 2005). 
gency means danger of disappointment and the necessity to take risks."100 This existential situation gives rise to eventual stable systems that stabilize expectations in relation to the environment. The presence of the alter ego, however, introduces uncertainty yet grants the opportunity to take others' experiences and "expand [one's] own horizon of experience without loss of time." ${ }^{101}$ The social world thus creates a double contingency, because the other is treated as an "I," yet he is able to act independently. What becomes important therefore is the certainty in the expectation of expectations rather than the fulfillment of expectations. Luhmann stipulates two kinds of expectations, cognitive and normative. Cognitive expectations are mediated by adaptation in the face of disappointment, whereas normative expectations persist and are not rejected no matter if they are acted against. In Luhmann's terms, "norms are counterfactually stabilised behavioural expectations. Their meaning implies unconditional validity.... The symbol of the 'ought' expresses primarily the expectation of such counterfactual validity without putting this quality of expectation to discussion." 102 And finally, law is defined as the "structure of a social system which depends upon the congruent generalisation of normative behavioural expectations." 103 Some systems are inherently unstable and require management; the market is a clear example. The structural coupling of the economic and legal systems through property and contracts enables the normative structures of the legal system to be available in the economic system.

Moving from the local, national context to the global arena creates vast new spheres of uncertainty as at this level the normative order is plural and fragmented, and likely to remain so. ${ }^{104}$ Therefore, in the "supranational context, more so than in domestic spheres, 'interlegality' and 'internormativity', that is, the relationships between a diversity of normative orders hold the key to legal certainty." There is scope for the interplay of power and consensus between organizations, professions, and business communities, which means normative expectations are integrated at lower levels of abstraction and generality because the role of law is

100. Nikgas Luhmann, A Sociological Theory of Law 25 (Martin Albrow ed., Elizabeth King \& Martin Albrow trans., 1985).

101. Id. at 26.

102. Id. at 33 .

103. Id. at 82.

104. See Andreas Fischer-Lescano \& Gunther Teubner, Regime Collisions: The Vain Search for Legal Unity in the Fragmentation of Global Law, 25 Mich. J. InT'L L. 999, 1000 (2004).

105. Volkmar Gessner et al., A4 Research Team, In the Shadow of the State? Autonomous Structures in Globalized Exchange Processes 26 (2005) (working paper, on file with U. of Bremen, Collaborative Research Center 597). 
diminished here. These structural conditions are amenable to the malleability and pragmatism of Anglo-American jurisprudence. Large law firms by virtue of their position in society and the economy are able to provide support structures for their clients, or attempt to manage uncertainty for them. They provide the legitimation, which has both cognitive and normative elements, about which Berger and Luckmann speak. ${ }^{106}$ For them, law is essentially one tool among many to be adopted and brought into play as and when required. Choice of law and laws, for example, is open and multivalent. International business agreements often require the coordination of several sets of laws and those which seem the most adaptable will be selected to act as the coordinators. In many cases, this role falls to New York state law and English law. ${ }^{107}$ Removing the state from the equation, for instance, by the use of international arbitration, is one method of managing expectations. Alternatively, parties may select a particular jurisdiction for disputing purposes, e.g., northern Germany or the Commercial Court in London. ${ }^{108}$ The point about disputing is that it usually occurs too late in the process to act as a stabilizing practice that delivers predictability and normalcy. Disputing often brings about a resolution that might entail the cessation of relations between the parties. The question then becomes: what is it that large law firms do to stabilize expectations?

There are, however, factors that go beyond the use of some form of law that induces stability. Lawyers themselves are members of coordinating networks that interact to bring about stabilization of expectations. In the first instance there are the law firms that are multinational by virtue of having many overseas offices. Secondly, there are the law firms that are single-jurisdiction based yet are plugged into a series of interlocking networks that create a set of "best friends," who provide extensive reliability and durability. Furthermore, these law firms are networked with a range of professional service firms, including banks, consulting firms, and accounting firms, among others. The intellectual forces of these firms endorse a set of actions that are co-extensive and display repeated patterns. In

106. See Berger \& Luckmann, supra note 12 , at 111.

107. Flood, supra note 6, at 252. For an example of U.S. law supplanting Russian law, see D. McBarnet, Transnational Transactions: Legal Work. Cross-Border Commerce and Global Regulation, in Transnational Legal Processes, supra note 59, at 98, $103-07$.

108. See, e.g., Volkmar Gessner, International Cases in German First Instance Courts, in ForeigN Courts: Civil Litigation in Foreign Legal Cultures 149, 150-58 (Volkmar Gessner ed., 1996); John Flood, The Cultures of Globalization: Professional Restructuring for the International Market, in Professional Competition and Professional Power: Lawyers, Accountants and the Social Construction of Mark ets 139, 150 (Yves Dezalay \& David Sugarman eds., 1995). 
Luhmann's terms these are typified solutions that are formulated in legal language that is part of a shared lexicon of meaning. ${ }^{109}$ There are many examples of these typified solutions that aim to establish certainty and stabilize expectations. Two are cited above: Jones Day's involvement with Dongfeng's restructuring and Freshfield's role in the development of the Sakhalin oil and gas extraction and refining. These examples illustrate how law firms attempt to establish certainty within a context of uncertainty and de facto lawlessness. Enabling and support structures via their typified solutions compensate for the power imbalances immanent in the market in its more rebarbative forms.

With these kinds of roles and activities, large law firms, in managing uncertainty and stabilizing expectations, create a set of solutions that function autonomously. That is, they do not supplant the state, but rather supplement the state in providing solutions or support structures that operate in independent contexts by virtue of consensus and authority granted by the status of the law firm itself. For example, certain "Magic Circle" law firms in London will refuse to use other firms' documentation because they consider their own to be of "holy" status not to be subverted by intermingling with heretical structures devised by others. It is the brute fact that the documentation in a transaction issued from a particular firm that, in part, enables the transaction to progress. In other situations it may be particular individuals who are able to sanction arrangements that are riven with uncertainty. The lawyer appointed as examiner, Richard Gitlin, in the first major cross-border insolvency, Maxwell, was able to exert tremendous authority by virtue of his long standing and high esteem within the community that had thought about the problems of cross-border insolvency. The protocol he developed to manage the incompatibilities between American and British insolvency regimes became a template for other similar cross-jurisdictional infractions. ${ }^{110}$ Would these kinds of transactions be possible without the endorsement and cooperation of large law firms? While it is not possible to give a dispositive answer, the evidence suggests it is unlikely.

\section{Case Study: Mimesis in the Covered Bond Market}

In this section of the paper I present a case study drawn from my empirical work. The case represents the creation of a special type of collateralized bond

109. See LuhmanN, supra note 100 , at 25-26.

110. John Flood \& Eleni Skordaki, Normative Bricolage: Informal Rule-making by Accountants and Lawyers in Mega-insolvencies, in Global Law Without a State 109, 125 (Gunther Teubner ed., 1997). 
known as "covered bonds." Covered bonds are defined as "securities backed by mortgages or public sector loans that remain on the issuer's balance sheet,"111 and "senior debt instrument[s] of the issuer having priority recourse to a pool of assets ringfenced from the other assets of the issuer, [which are] often regarded as substitutes for government debt."112

The secondary market in mortgages is huge. In 2004, the European Central Bank (ECB) reported that the volume of mortgage loans in Europe exceeded 4 trillion and was growing at the rate of 8 percent a year. ${ }^{113}$ But it is an area in which there is little European integration, and as the ECB pointed out,

Less than $40 \%$ of mortgages are financed via the capital market, the remainder is deposit financed. The two capital market instruments to fund mortgages-covered bonds and residential mortgage backed securities (RMBS) - are heterogeneous across countries because of differences in legal, tax and regulatory frameworks governing issuance in the respective jurisdictions. Those cross-country differences have prevented a geographic diversification to take place. So far mortgage loan portfolios that underlie covered bond issuance or are backing RMBS transactions have been purely domestic. ${ }^{114}$

In some European countries, such as Germany, France, and Ireland, legislation exists to issue covered bonds, but not in the United Kingdom. In Germany, the mortgage-backed bond is called the Pfandbriefe (under the German Mortgage Bank Act of 1900). In this situation the bank issues bonds which are secured on a ringfenced pool of mortgage-backed assets. The legislation protects them in the event of the bank's insolvency so that the bondholders are ahead of other creditors. The bonds have a low-risk rating and the assets have to match the outstanding claims

111. A BN-AMRO, Glossary, The Definitive Guide to Investment Banking, http://www.graduate.abnamro.com/glossary.do (last visited Nov. 15, 2006).

112. Arjan Verbeek, Barclays Capital, Understanding UK Covered Bonds: Development And Future Growth (2005), http:/www.cml.org.uk/cml/filegrab/Funding-ArjanVerbeek. pdf? ref $=4451$.

113. Gertrude Tumpel-Gugerell, Member of the Executive Board of the European Central Bank, Speech at the European Mortgage Federation Annual Conference: Capital Markets and Financial Integration in Europe (Nov. 23, 2004) (transcript available at http://www.ecb.int/press/key/ date/2004/html/sp041123.en.html).

114. Id. 
and indeed should exceed the assets to provide a cushion. The bank is obligated to top up the assets as and when required. These bonds are particularly useful for regulated entities like insurance companies because of their safety, having a risk weighting of 10 percent. ${ }^{115}$

Figure 1: The Structure of a Pfandbriefe

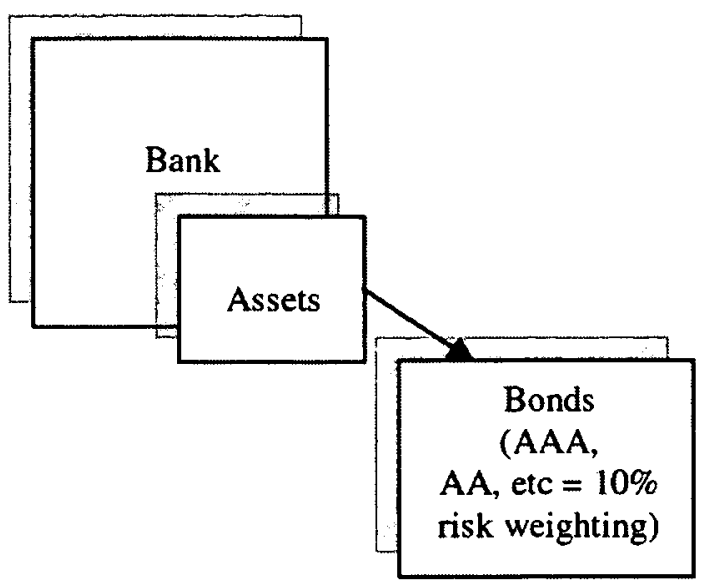

In the United Kingdom, because no legislation existed, a functional equivalent was crafted through contract, which had to be credible to city investors in the continuing absence of specific legislation. The lawyer, a securitization partner in a large city law firm, was approached by one of the major investment banks, in conjunction with a commercial bank, to structure a vehicle that would achieve similar results to the Pfandbriefe. The bank wanted to issue bonds over a pool of assets held by a bank, which would have a 20 percent risk weighting. The lawyer's structure entailed a bank issuing bonds that were triple A rated by the credit rating agencies. Then a limited liability partnership (LLP), a tax transparent vehicle, was created and from the proceeds of the bonds the bank made a loan to the LLP. The LLP used the loan to pay the purchase price of a pool of mortgage loans and then the LLP guaranteed the obligations of the bank under the bonds. This gave the bondholders access to the assets of the LLP if the bank became insolvent. And the bank ensured the pool of assets was topped up. ${ }^{16}$

115. See Figure 1 (based on drawings done by the lawyer during the interview).

116. See Figure 2 (derives from the same meeting as Figure 1). 
Figure 2: The Composition of a UK Covered Bond

Key: $L$-loan (100); $P$-price (100); $M$-mortgage loans; $G$-guarantee

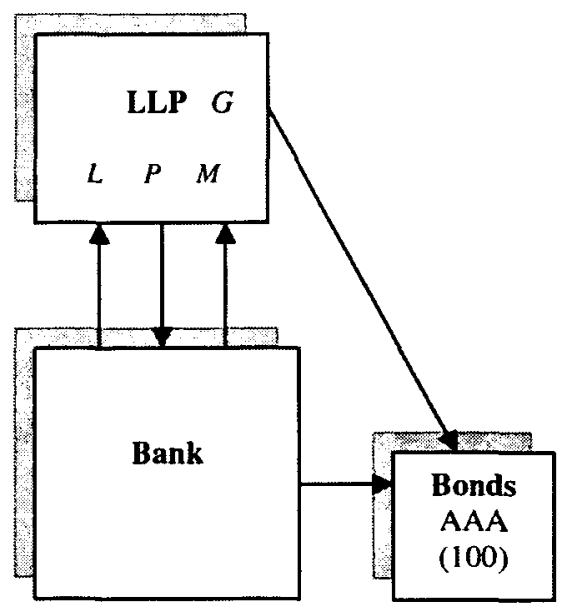

The limited liability partnership was used in preference to a special purpose vehicle to avoid the difficulties trust law imposed and to keep it within the bank, since the deal was not done off-balance sheet. ${ }^{117}$ The bonds were also over-collateralized by the assets being about 50 percent more than needed to cover the bonds. This was a requirement of the credit rating agencies in order for them to give the bonds a triple A rating. The bank, being one of the members of the LLP, then had a greater share of equity because of the over-collateralization and received the excess back by virtue of a capital distribution. As the lawyer pointed out, "It's quite tidy."

The first covered bond, worth $€ 3$ billion, was issued by HBOS in conjunction with Dresdner Kleinwort Wasserstein, Goldman Sachs, and Citigroup. HBOS needed to fund its balance sheet-as opposed to going off-balance sheet with many debt vehicles-so even though it used techniques of the securitization process it was "'structured not be a credit product'... The aim was to produce a true swaps/government bond substitute." 118 It was long and expensive to prepare because the " $[r]$ ating agencies together required five legal opinions before giving [it] their top ratings." 19 Figure 3 shows how the HBOS covered bond was struc-

117. If a special purpose vehicle were used, it and its assets would have had to have been remote from the originating bank in order to protect it in the event of the bank's bankruptcy.

118. Monica Vetter \& Alex Chambers, Thomson Financial, HBOS Opens the Structured Door, INT'L FIN. Rev., 2003, http://www.hbosplc.com/treasury/Covered\%20Bond.pdf.

119. Id. 
tured. ${ }^{120}$ Since the HBOS issue, at least four other financial institutions have followed with their own covered bonds.

Figure 3: HBOS Covered Bond Structure

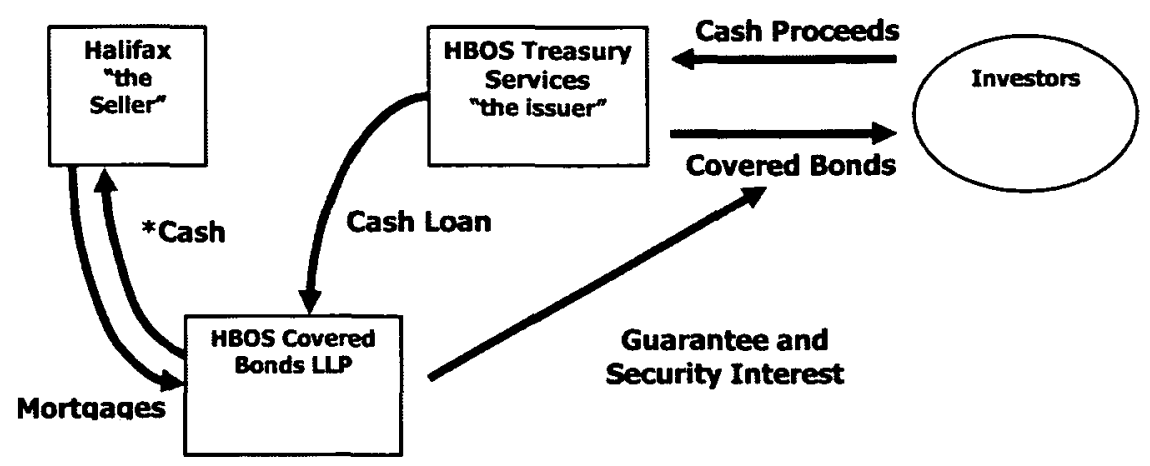

*includes Capital Contribution + Deferred Consideration

The U.K. covered bond created considerable controversy. Its key component was that because it was created in conjunction with U.K. insolvency law, the U.K. bond had greater protection than its German equivalent. This meant that the returns to the U.K. bond were also greater, which pulled investors from the Pfandbriefe market to the U.K. covered bond. Figure 4 shows how the U.K. covered bond compares with others in Europe that are approved by legislation. Not only does it target the residential mortgage market, it has high bankruptcy protection and high credit ratings. The Pfandbriefe suffers in all elements by comparison with the U.K. covered bond. ${ }^{121}$

120. See Figure 3. HBOS Treasury Services, UK Covered Bond Programme, Slide 5, http://www. hbosplc.com/treasury/presentations/041018\%20Cov\%20Bond.pps (last visited Nov. 15, 2006).

121. See Figure 4. HBOS Treasury Services, UK Covered Bond Programme, Slide 10, http:// www.hbosplc.com/treasury/presentations/041018\%20Cov\%20Bond.pps (last visited Nov. 15, 2006). 
Figure 4: UK Covered Bond Comparisons

\begin{tabular}{|c|c|c|c|c|c|}
\hline & $\begin{array}{c}\text { UK Covered } \\
\text { Bonds }\end{array}$ & $\begin{array}{c}\text { Pfandbriefe } \\
\text { (Germany) }\end{array}$ & $\begin{array}{c}\text { Obligations } \\
\text { foncières } \\
\text { (France) }\end{array}$ & $\begin{array}{c}\text { Cédulas } \\
\text { (Spain) }\end{array}$ & $\begin{array}{c}\text { Irish ACS } \\
\text { (Eire) }\end{array}$ \\
\hline Ratings & AAA/Aaa/AAA & Varies & AAA/Aaa/AAA & Varies & AAA/Aaa/AAA \\
\hline $\begin{array}{c}\text { Bankruptcy } \\
\text { Remoteness }\end{array}$ & $\checkmark \checkmark \checkmark$ & $\checkmark \checkmark$ & $\checkmark \checkmark \checkmark$ & $\checkmark$ & $\checkmark \checkmark \checkmark$ \\
\hline $\begin{array}{c}\text { Common } \\
\text { Risk } \\
\text { Weighting }\end{array}$ & $20 \%$ & $10 \%$ & $10 \%$ & $10 \%$ & $10 \%$ \\
\hline $\begin{array}{c}\text { Collateral } \\
\text { Type }\end{array}$ & $\begin{array}{c}\text { Residential } \\
\text { Mortgages }\end{array}$ & $\begin{array}{c}\text { Public Sector } \\
\text { Mortgages }\end{array}$ & $\begin{array}{c}\text { Public Sector } \\
\text { Mortgages }\end{array}$ & $\begin{array}{c}\text { Public Sector } \\
\text { Mortgages }\end{array}$ & $\begin{array}{c}\text { Public Sector } \\
\text { Mortgages }\end{array}$ \\
\hline Liquidity & $\checkmark \checkmark \checkmark$ & $\begin{array}{c}\checkmark \checkmark \checkmark \\
\text { (Jumbo) }\end{array}$ & $\checkmark \checkmark$ & $\checkmark \checkmark$ & $\checkmark \checkmark \checkmark$ \\
\hline
\end{tabular}

The German mortgage banks presented their dislike of the U.K. covered bond by arguing it was not in accord with the EU directive. The English banks were uneasy because they wanted to reduce the risk weighting from 20 percent to 10 percent, which led them to lobby the Treasury and the FSA to legislate. ${ }^{122} \mathrm{Fi}$ nally, after a period of three years, the Treasury has agreed to enact legislation. ${ }^{123}$

\section{Reflections and Conclusions}

The following are a series of conjectures and ideas flowing from the case study. Most are based on comments by lawyers who were interviewed during this project.

1. Big law firms get work because they are big law firms and clients return. The lawyer in the case study said:

It's chicken and egg. As a group, the group I've worked with has always tried to do cutting edge deals. And once you've done one people tend to trust you and come to you with a wacky idea. That's one aspect.

122. See Creditmag.com, Credit Forum, Uncovering Covered Bonds (May 1, 2004), http://www. creditmag.com/public/showPage.html? page $=154079$.

123. Christopher Adams \& Paul J. Davies, Boost to Market for Covered Bonds Could Lead to Cheaper Home Loans, Fin. Times (London), June 30, 2006, at 3. 
The thing about securitization in particular is that it's dominated by four firms and people tend to go to one of those four. It's just such a habit that it's not always the lawyers which are doing the creative thinking. It's always in conjunction with an idea that we'll work in partnership particularly with lead arrangers-Citigroup, Goldman Sachs especially. And we work a lot with them in terms of new ideas. ${ }^{124}$

2. Despite the fact that law firms are more fluid entities than in the past with lawyers migrating from firm to firm, clients will cleave to a particular firm rather than always follow the lawyer. One lawyer interviewed noted:

I think that sometimes with clients it's a matter of trust. They'll go to ["Flood \& Sosa"] law firm because they know they can do this. Because sometimes it's not the person but actually the brand of the firm. They'll say I know with ["Flood \& Sosa"] I get the team not just the lawyer. ${ }^{125}$

Big firm lawyers also tend to work with business people. Even though their clients-corporations, investment banks, property companies-have in house counsel, it is the business side that calls the shots. And they often prefer to work with lawyers directly rather than mediate through counsel.

The big law firms go hand in hand with the big investment banks that have their European headquarters in London. Other European offices tend to deal with local matters. One interesting element remarked on by a lawyer was:

Only a minority of people working at the big banks are English. Most of the investment bankers come from anywhere. Lots of Italians, lots of Americans, lots of Germans, even some of Dutch people. And they tend to be the best, the most qualified. Even if they are not English, they will turn to English firms to run a deal because we have some of the biggest city offices in the world as well as some of the biggest firms. And so that automatically means with size comes depth. Depth of experience, having done things before, and sophistication. ${ }^{126}$

124. Interview with large law firm corporate lawyer, in London, Eng. (May 2005).

125. Interview with large law firm corporate lawyer, in London, Eng. (May 2005).

126. Interview with large law firm corporate lawyer, in London, Eng. (Apr. 2005). 
3. Anglo-American law is sovereign. Path dependency plays strongly here. A lawyer pronounced, for example in connection with English law, that, "People find certainty in English law and English law is a lot more creditor friendly than the other continental jurisdictions. The contract is king. People tend to be a lot more comfortable because the documents tend to be the deal; there's less that's left unsaid but remaining in legislation." Another lawyer said, "Obviously you take account of the peculiarities of national law, but the agreements look the same and they will almost always be in the English language. Even in France where it's technically illegal, but people pay their $€ 300$ fine for having their agreement in English." A senior partner commented on one of his transactions that local law could not be ignored:

We were handling a very large multinational acquisition involving subsidiaries and so forth in a number of countries. The question was how to draft documents that would bring all that together in a uniform way. What I did was to have all the local variations drafted under their own laws, then I constructed a master umbrella agreement under English law that tied all of them together and yet recognized their differences. It was quite hard to do. ${ }^{127}$

This is analogous to Smets' idea of lawyers de-contextualizing idiomatic legal wording and so constructing a disembedded core. ${ }^{128}$ The process is imbricated in a turf war between lawyers from different jurisdictions competing to impose their claim controlling the process. ${ }^{129}$

Yet another lawyer pointed out that the use of New York and English law depended on whether the transaction was taking place in the western or eastern hemisphere. The former used New York, the latter used English. But, ultimately, the banks decide the issue. However, from the client's perspective it is different, as this lawyer noted:

If a company has a relationship with a particular law firm or particular person or partner they tend to work with that person or that type of form and most clients don't care about governing law. They

127. Interview with large law firm corporate lawyer, in London, Eng. (Sept. 1995).

128. Michael Smets, Aligning Local Expertise in Cross-National Legal Work: Translations in a Global Law Firm's Banking Group (2006) (unpublished paper, on file with author).

129. Id. 
are concerned about commercial matters and the agreement is just a reflection of what was the end of negotiation result. ${ }^{130}$

\section{Virtually all the work is performed through standard documentation, which is} then varied to suit the particular transaction. A law firm builds its social and intellectual capital, as a lawyer put it, on the quality of its document library. Some firms have been known to refuse to accept documents drafted by another firm because they consider them of inferior quality. Not all transactions fit into typical standard forms. One lawyer told of a deal that involved a securitization restructuring a trust:

We'd never drafted a mortgages trust before so we started by going down to the private client department that deals with trusts and trustees all the time. You start with a simple document and change it. There's lots of free drafting when you do something new. We rely on the other side to review it, and the rating agencies. And if there are real estate or tax issues my colleagues there will review it. ${ }^{131}$

There has to be agreement about who drafts the initial documents. It is customary for the seller to provide the documents; if a transaction was a bi-lateral sale and purchase, custom would dictate that the purchaser provide the documents. The key point here is that whoever originates the documentation has considerable control over its life course and final composition. It is a position of power.

5. Because of the way law firms are organized, choosing who works on a transaction is never straightforward. In the case study, the lead partner used about nine other lawyers in the transaction. As Lazega has demonstrated, a law firm is a "Montesquieu structure," 132 which entails interdependent niches negotiating the deployment of resources within the firm. Two sets of negotiations are involved: which associates and other partners within the immediate group will work on the deal and which lawyers from other groups in the firm will be involved. Added to this is the problem endemic to large law firms of how competent lawyers are identified and judged within a large firm. Networks seek to distribute information

130. Interview with large law firm corporate lawyer, in London, Eng. (Apr. 2005).

131. Interview with large law firm corporate lawyer, in London, Eng. (May 2005).

132. LAZEGA, supra note 39 , at 39. 
that attests to the knowledge and reliability of others, but often the information is dispersed. Finding a lawyer within a large law firm can be as difficult as finding a law firm or lawyer in another country.

6. It is now possible to see how stability can be generated. The difficulty inherent in the double contingency of action is overcome by providing congruently generalized normative behavioral expectations. ${ }^{133}$ Big law firms play a considerable role in generating these expectations. Their lawyers and their standard documentation all regress to risk averse means. The very name of a firm signifies more than the sum of its parts. For example, for a long time Japan forbade the use of firm names by foreign law firms. The only names permitted were the names of the partners present in Japan. Western law firms could not establish their identities. Recent changes in Japanese laws on the legal profession and the influence of the General Agreement on Trade in Services (GATS) have allowed foreign law firms to use their "brand" names. ${ }^{134}$ Branding has become a crucial element in determining and securing the value of a law firm. But it is not just the brand; it is also the collective spirit of the law firm, it being a dynamic entity, that enables it to confirm that transactions will be accepted as real, true, and valuable by the commercial community at large. I return to my original claim that large law firm lawyers are endowed with priestly attributes, that by conferring their imprimatur on the transaction, the profane becomes sacred and believers have faith.

133. Luhmann, supra note 100 , at 26.

134. See Leonardo Ciano \& Drew Martin, Japan's Foreign Lawyer Law: Disparate Views, 1 ALSB INT'L Bus. L.J. 101 (2001), available at http://www.alsb.org/international/ijrnl/ciano-martin/text. htm. 